University for Business and Technology in Kosovo

UBT Knowledge Center

UBT International Conference

2015 UBT International Conference

Nov 7th, 9:00 AM - 5:00 PM

\title{
Strengthening Artisanry by Associating it with Tourism (Region of Shkodra)
}

\author{
Ermira Qosja \\ European University of Tirana, ermira.qosja@uet.edu.al
}

Vasilika Zeka

European University of Tirana, vasilikazeka@yahoo.com

Follow this and additional works at: https://knowledgecenter.ubt-uni.net/conference

Part of the Business Commons

\section{Recommended Citation}

Qosja, Ermira and Zeka, Vasilika, "Strengthening Artisanry by Associating it with Tourism (Region of Shkodra)" (2015). UBT International Conference. 19.

https://knowledgecenter.ubt-uni.net/conference/2015/all-events/19

This Event is brought to you for free and open access by the Publication and Journals at UBT Knowledge Center. It has been accepted for inclusion in UBT International Conference by an authorized administrator of UBT Knowledge Center. For more information, please contact knowledge.center@ubt-uni.net. 


\title{
Strengthening Artisanry by Associating it with Tourism (Region of Shkodra)
}

\author{
Ermira Qosja ${ }^{1}$, Vasilika Zeka ${ }^{2}$ \\ ${ }^{1}$ Department of Management and Economics, European University of Tirana \\ ${ }^{2}$ European University of Tirana \\ ermira.qosja@uet.edu.al', vasilikazeka@yahoo.com²
}

\begin{abstract}
Culture is one of the greatest assets of a country, and it has the potential to become a source of income, if it is managed effectively. The handcrafts of the Albanian artisanry are a part of our culture, but still far from having an effective role in the development of tourism. Associating artisanry with tourism is of great interest for the present, as well as the future of the Region of Shkodra, and studies to this end are important.The objective of this paper is to study the effect of the growth of tourism in the increase of sale of handcrafts. First of all, the paper intends to ascertain whether the tourism peak season brings also higher sales of handcrafts; second, whether the craftsmen recognize the tourist-customer; third, whether the craftsmen try to adjust their handcrafts to the tourist-customer requirements; fourth, what do the tourists think of such handcraft; and fifth, to ascertain the sales channel of the handcrafts in order to have a clear picture of what it takes for the artisanry products to move for the craftsmen to the customers and to identify unexploited potentials that would strengthen this industry. This research is based on secondary data sourced from the official sites of government and non-government organizations, and on primary data sourced through semi-structured interviews with artisanry experts, as well as on two surveys: one conducted with the craftsmen and the other one conducted with tourists. The results presented in this paper would help to recognize and understand the present situation of the artisanry in the Region of Shkodra, as well as serve as basis for some recommendations to further vitalize and develop this industry.
\end{abstract}

Keywords: artisanry, tourist, sales channel, Region of Shkodra.

\section{Introduction}

Artisanry, which is otherwise known as the "creative industry", is a special sector of the economy which, in spite of the development of science and technology throughout the world economy, did not lose any of its value. On the contrary, this sector affirmed itself to become a source of employment, especially in the rural areas. The creative industry accounts for the 7 percent of the global GDP, with a growth rate of 8.7 percent. The greater part of the products related to culture are exported from the developed countries, whereas the developing countries, in spite of their talents and rich culture, represent only 1 percent of the total exports.

Artisanry should be considered as a sector in need of stimulation to develop, since it is a promotor of including the developing countries in the global trade, as well as an important income generator, since it creates new jobs and empowers artists and people (intracen.org, 2015). The unique decorative, functional, artistic, religious and social nature of handcrafts makes them closely related to the culture of the country and its tourism (Kola, 2013).

Meanwhile, the sustainable development of tourism makes it imperative to part away from the tourism of three S's (sea, sand, and sun) and move towards alternative tourism. To this end, its development is achieved through three main approaches: economic development, sustaining social and cultural tissue, and sustaining environment (Report on Sustainable Tourism in the Mediterranean, 2013).

When taking into consideration what tourists demand, the main requirement for a sustainable tourism is the cultural authenticity (CESD \& TIES, 2005). Cultural heritage comprises the way of life, cultures, as well as historical, archaeological and religious buildings and places. Tourism offers the possibility to sustain, revive and develop the tradition, making it a way of life which generates income. 
The Mediterranean basin is one of the main tourist destinations, welcoming 30 percent of the worldwide tourists and accounting for 25 percent of the global income generated by this industry (Report on Sustainable Tourism in the Mediterranean, 2013).

If due attention is given, associating artisanry to tourism could result effective to both sectors of the economy. On one hand, handcrafts attract tourists, since they arouse interest, and, on the other hand, tourists stimulate their production, since they would want to buy them, or the hospitality industry would use them to decorate their accommodation facilities.

The main purpose of this paper is to describe the actual situation of artisanry in the region of Shkodra, to argue through the research undertaken that relating it to tourism could strengthen this sector, and to analyze the sales channels of artisanry products.

Objectives of this paper include, first, to describe the actual situation of artisanry in the region of Shkodra; second, to identify the problems artisans of this region face; third, to present the tourist behavior towards handcrafts; and fourth, to identify the present channels and potentials of sales.

The research question posed by this paper is: Could artisanry in the region of Shkodra be strengthened by associating it with tourism? Three auxiliary questions are also raised to help in this undertaking: Question 1 - Does a growing number of tourists bring about greater sales of handcrafts? Question 2 Are the handcrafts attractive to tourists? Question 3 - Are there any unexploited sales channels for the handcrafts?

On such basis, three hypothesis are raised in this paper: Hypothesis 1 - The growth of tourism brings about a growth in handcrafts production. Hypothesis 2 - Handcrafts are a possibility to tempt tourists to spend more. Hypothesis 3 - New sales channels could help grow handcrafts sales.

This paper is based on a number of secondary sources, including books, catalogues, studies on tourism and artisanry published online, official websites of government and non-government organizations, information collected from direct contacts with associations concerning artisanry, as well as a number of primary sources, such as an interview with Mr. Zef Gjini, Chairman of the Artisans Association of Albania, and data obtained from the two semi-structured interviews: one with 24 artisans, occasionally interviewed during a fair in Shkodra and/or in their shops, and another one with 101 tourists.

Analyzing the two questionnaires yielded results which help draw some valuable conclusions and recommendations to private and public operators interested in developing tourism, artisanry and the economy of the region of Shkodra, but not only.

\section{Artisanry industry and its distinctive features in Shkodra}

Defining and assessing artisanry varies from country to country. However, in the international symposium Crafts and the International Market: Trade and Custom Codification, organized by UNESCO and ITC in 1997, handcrafts are defined as follows:

Artisanal products are those produced by artisans, either completely by hand, or with the help of hand tools or even mechanical means, as long as the direct manual contribution of the artisan remains the most substantial component of the finished product. These are produced without restriction in terms of quantity and using raw materials from sustainable resources. The special nature of artisanal products derives from their distinctive features, which can be utilitarian, aesthetic, artistic, creative, culturally attached, decorative, functional, traditional, religiously and socially symbolic and significant (UNESCO, 1997: 6).

Based on the materials used, handcrafts could be divided into six main categories (Nugue, 1990: 4): 1. Basketry (handcrafts made of fibrous or pliable materials, such as pine straw, stems, grasses, thread, and fine wooden splints, which would include toys, musical instruments, costumes, etc.); 2. Metal (iron, copper, brass, precious metals, etc.); 3. Leather (leather of different animals); 4. Pottery (fired ceramics, glazed and unglazed); 5. Textile (embroidery and weaved fabrics using plant and animal fibers, such as wool, linen, silk, etc.); 6. Wood (various crafts made of wood from trees or other plants). The history of Albanian artisanry is pretty old and closely related to the history of country itself. Shkodra, with its 2500 years old history and its rich artisanry heritage, is not an exception to this. Artisanry in Shkodra flourished from the middle of $18^{\text {th }}$ century until the middle of the $19^{\text {th }}$ century. During this period, Shkodra was the center stage for all artisans, with shops covering up to 
80 different kind of crafts. Artisans used to give different shapes to stone, wood and iron, they weaved and embroidered various traditional costumes with golden and silver filigree, they worked on leather, etc. Chroniclers and foreign diplomats have all confirmed that artisans of Shkodra were true masters of art:

"Tailors and embroiderers of Shkodra are exceptional in embroidering fabrics with golden filigree and silk, and they sell as far as Bosnia and Rumelia." Austrian Consul to Shkodra, Th. A. Ippen, 1898 (Shkoder, 2007)

"A good handicraft has a golden foundation." (Proverb)

"A craft is a like a priceless decoration." (Proverb)

After 1944, artisans were organized into artisanry cooperatives and, later on, into a state-owned artistic enterprise. Thus, artisans were made to work together and produce not only for the local market, but for expert, too.

The radical changes at the beginning of 1990s brought about new challenges to the artisanry. The state-owned artistic enterprise of Shkodra dissolved and disappeared, giving birth to various private initiatives. Nowadays, in the region of Shkodra are to be found unique handcrafts of filigree embroidery, wood, stone, bulrush, etc., that represent products with functional and artistic value. For these reasons, Shkodra is considered as the busiest city with artisanry activities, of which the products are so unique that each of them could be considered a micro value chain (UNDP, CIS \& UNOPS, 2011: 48).

The forms of organization of the artisans are a bit hard to define, since a good part of them operate informally (Zef Gjini). However, even though operating informally saves them from paying taxes, this hampers opportunities that may arise from foreign or government donations.

Yet, it must be noted the willingness of artisans to be organized into associations and foundations, which would facilitate taking part into fairs or receiving grants. The project conducted by MADA is such an initiative, which served to build the website of the Artisans Associations of Albania, to produce and distribute $500 \mathrm{CDs}$ to promote handcrafts of Shkodra, and to facilitate and organize the National Artisanry Fair, in Velipoje. Meanwhile, another similar project, named Growth Albania, funded by USAID, aimed at promoting new artisanry products (Artisans Association of Albania, 2015). On the other hand, Addressing the Challenge of Youth Employment at Local Level was a project undertaken by NBS, which focused on training youth in artisanry in order to help them find a job. About 100 youths were trained to work on filigree, pyrography, loom, waving carpets, crochet work, embroidery, etc. (NBS - Social Business Promotion Association, 2014).

It must be noted that this sector has also received the backing of government policies. By 28 March 2014, a plan to disburse financial assistance was approved, based on the Council of Ministers Decree, which had created a fund for the creative industry. This fund is intended to support artisanry in Albania, with the objective to create a favorable environment for a more sustainable economic development, as well as create new jobs. On top of that, part of the National Tourism Strategy 2014 2020 has also become the resolve "to support measures which integrate local craftsmanship with the tourism offer" (Ministry of Tourism, 2014: 58-59).

\section{Methodology of research}

In order to fulfill the purpose of this paper, which is to describe the actual situation of artisanry in Shkodra, as well as to argue through the research undertaken that associating it to tourism could strengthen this sector and to analyze the sales channels of artisanry products, the research question being raised is: Could artisanry in the region of Shkodra be strengthened by associating it with tourism? Three auxiliary questions that are also raised are: Question 1 - Does a growing number of tourists bring about greater sales of handcrafts? Question 2 - Are the handcrafts attractive to tourists? Question 3 - Are there any unexploited sales channels for the handcrafts?

Following the above, three hypothesis are raised, which are: Hypothesis 1 - The growth of tourism brings about a growth in handcrafts production. Hypothesis 2 - Handcrafts are a possibility to tempt tourists to spend more. Hypothesis 3 - New sales channels could help grow handcrafts sales. 
According to the representatives of the Artisans Association of Albania and the Association of Professional and Artisan Women, there are over 100 artisans in the region of Shkodra. The semistructured questionnaire, drafted to obtain the needed information, was distributed among the artisans at the National Artisanry Fair, on 10 June 2015 (Plus, 2015). The time and place were suitable, which helped to conduct the semi-structured interviews, from which were identified challenges and opportunities faced by the artisanry (creative) industry. Meanwhile, some others were contacted in their shops, in Shkodra, which were randomly selected. In total, the number of artisans surveyed is 24. The sample selected has the following characteristics: as per gender: 71 percent are women; as per age: 13 percent are under the age of 25 years old, 25 percent are between 36 and 45 years old, 62 percent are above 45 years old; as per education: 21 percent have completed their basic education only, 67 percent have finished their high school, 4 percent have a bachelor's degree, 8 percent have a postgraduate degree; as per their experience as artisans: 12 percent have 5 years of experience, 4 percent have between 6 and 10 years of experience, 50 percent have between 11 and 20 years of experience, 13 percent have between 21 and 30 years of experience, 21 percent have more than 30 years of experience; as per form of business organization: 88 percent are individual businesses, 8 percent were joint-ventures, 4 percent are informal businesses; as per the number of employees: 71 percent have between 1 and 3 employees, 21 percent have between 4 and 7 employees, 8 percent have between 8 and 10 employees. The questionnaire for the tourists was intended to analyze the relation of tourists with the handcrafts, and the factors which influence that behavior. The sample of tourists was randomly selected, where 101 foreign tourists were interviewed through the semi-structured questionnaires in English language. The sample selected were from different countries and they were contacted while staying in Shkodra. During the open questions, tourists did not hesitate to give their opinion, provided that they had prior knowledge. Yet, even though they were collaborative, it must be noted that they had no prior knowledge. The sample selected from the tourists has the following characteristics: as per country of origin: they are from 24 different countries, where 17 percent are from the United States, 11 percent from the Great Britain, 8 percent from Russia, 6 percent from France and Sweden, 5 percent from Belarus, Israel and Malaysia, 4 percent from Poland, Montenegro, Switzerland and Austria; 3 percent from Germany, Czech Republic and Kosovo, the rest are almost evenly from other remain countries; as per gender: 57 percent are males, 43 percent are females; as per age: 1 percent are under the age of 18 years, 21 percent are between 18 and 25 years old, 31 percent are between 26 and 40 years old, 25 percent are between 41 and 55 years old; as per civil status: 42 percent are single, 44 percent are married, 14 percent are living-in; as per repeatability of visit: 74 percent are for the first time in Shkodra, 26 percent have visited Shkodra more than once; as per purpose of visit: 14 percent are for business, 69 percent are on vacation, 11 percent are visiting relatives or friends, 6 percent were on transit.

\section{Research findings from the artisan survey}

With the exception of 17 percent of them, who make use of middlemen, almost all artisans sell their crafts themselves directly to customers. Selling them themselves directly to the customers, according to the artisans, is a better opportunity to explain more about the history of the product, to talk about all the art and meticulous work that goes to the product, and a better way to increase their profits. On the other hand, it must be noted that, taking into consideration their education and age, their communication and promotion technique is very limited, thus harming also their potential to increase contacts with the market. Meanwhile, those 17 percent who use middlemen, or indirect channels, affirm to have understood the importance of quick distribution that such a method offers. The question "Where is sold the major part of your products?" has received the answers elaborated in Table 1: 
International Conference on Management, Business and Economics, Nov 2015

\begin{tabular}{|l|l|l|}
\hline $\begin{array}{l}\text { Place of sale of } \\
\text { products }\end{array}$ & $\begin{array}{l}\text { Absolute frequency (in } \\
\%)\end{array}$ & $\begin{array}{l}\text { Relative frequency (in } \\
\%)\end{array}$ \\
\hline My shop & 12 & 50 \\
\hline Supply to other shops & 3 & 13 \\
\hline Fairs & 11 & 46 \\
\hline Welcoming centers & 0 & 0 \\
\hline Other & 3 & 13 \\
\hline Total & 24 & \\
\hline
\end{tabular}

Table 1: Presentation of place of sale of products (Authors)

Artisans mostly sell at their own shops (50 percent of them) and in fairs (46 percent of them). However, there is a part them which use combined sales channels, such as selling to embassies, selling to their friends locally or abroad, etc. Yet, this is still a small part of them (13 percent of them). Even though, by analyzing the interviews, the dissatisfaction of the artisans with the level of their sales is very striking, the greater part of their products is sold at different fairs. But, the number of fairs being held is small, the advertising space is limited, and the number of artisans taking part is not greater than 30 percent of the total (only the members of the Artisans Association of Albania).

The questions "Do your customers return back?" and "Do you keep contacts with your customers?" have received the answers elaborated in Figure 1:

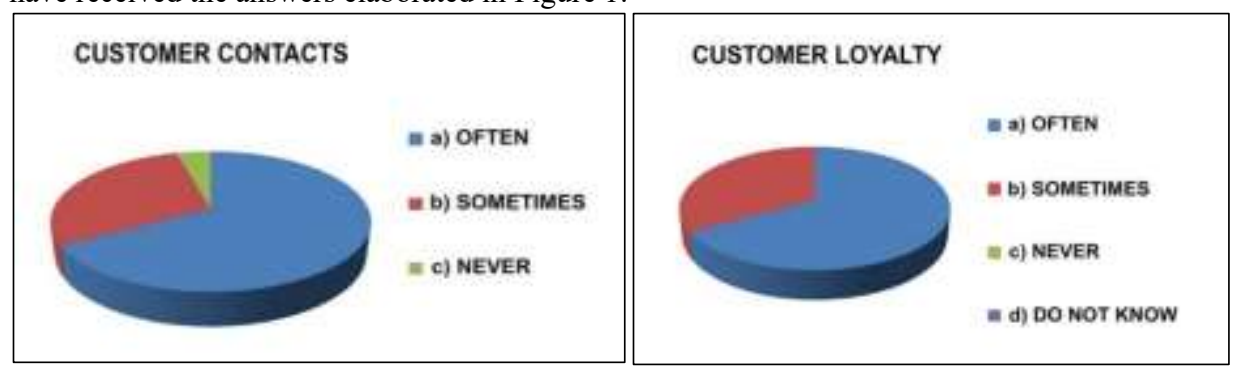

Figure 1: Graphical presentation of the contacts with customers and customer loyalty (Authors)

Looking at the answers given, there is a correlation between the contacts artisans keep with their customers and the level of customer loyalty (67 percent of the customers are contacted often and exactly 67 percent of them return to buy again). That which strengthens the bond between artisans and their customers is the adaptation of their products to the customers' needs.

To the question "Have you ever made a new product or modified an existing product according to a customer's requirements?", 63 percent of the artisans have answered positively. An example would be the workshop of Gjino Mjeda, which introduced a new line of clothing and, after looking at the customers' response, made it part of his production lineup. On the other hand, 29 percent of the artisans rarely modify their products. A reason for this is also the fact that they do not receive such requests for modification.

To the question "The greater part of your customers are locals, they are in equal numbers with foreigners, or the foreigners for the greater part?", 42 percent of them have stated that most of their customers are locals, another 42 percent have stated that their customer base is equally spread between locals and foreigners, and 16 percent have stated that most of their customers are tourists. In the last group, the fairs play an important role, as well as Albanians living abroad who buy handcrafts, especially textile products, for their homes in the countries they live or to use them as gifts for their friends, which is also a way to show their recognition for the country of their origin. It must be noted that artisans do not view their products as an attraction for tourists and do not engage them directly. They usually tend to wait for others to bring tourists to them, so that they profit from what tourists buy. It is clear that there is a lack of awareness on importance of tourists, artisans lack even the elementary knowledge of English language, and they do not enter into agreements with tourism agencies so that these could make their shops part of the tours they organize for tourists. 
It is interesting to note the seasonality of the sales. Talking to artisans, there is a general consensus that the higher sales take place during summer ( 83 percent of the artisans affirm this). The growing number of tourists is the main reason for this. Concerning the ease of access to their shops, 46 percent of the artisans have stated that their shops are easily reached by customers, 29 percent of them have stated that there is a degree of difficulty to reach their shops, and 25 percent of them have stated that their shops are hard to identify. It could prove effective to organize artisans and bring them together into a common market for them to sell their products, since customers could be better attracted because they would find all sorts of handcrafts under one roof.

"How well do artisans know their customers?" is the other questions, to which 50 percent of the surveyed artisans answered "I know them very well" and the other 50 percent answered "I know them a little". However, there is a prevailing opinion that their answers are somewhat general, rather than a reflection of what it means to really know the psychology of the customer. To the question "Have artisans received any support from government or non-government organizations to develop their business?", 71 percent of them responded negatively. However, the remaining 29 percent of them have received support from organizations, such as AIDA, MADA, SHGPAZ, and SHASH.

Considering the kind of work that artisans do, it was expected that 54 percent of them would respond better to the question "How do you foresee the future of your business?". Meanwhile, 29 percent of them expected it to be the same, whereas 17 percent said that they foresee a worse future. The main problems raised were the lack of government support and high taxes (stated by 21 percent of the artisans surveyed), high cost of raw materials (stated by 17 percent of artisans), the negative impact of economic recession, and lack of cooperation with tourism operators.

\section{Research findings from the tourist survey}

The tourist is an important customer for the artisanry, yet the attention given is not enough. Considering the hypothesis raised, understanding the tourists' purpose of visit in Albania, and particularly in Shkodra, is of outmost interest. The result was that about 70 percent of them come on vacation.

To the question "Have you seen any handcrafts exposed near your vacation spots?", 74 percent of the tourists surveyed stated that they had never seen any handcrafts exposed. However, the other 26 percent of them responded that they had actually seen such products and they had even bought them. The answers given to the question "How do you value the artisanal products (from 1 - nothing interesting to 5 - very interesting)" are elaborated below, in the Table 2 and Figure 2:

\begin{tabular}{|l|l|l|l|l|l|l|l|}
\hline $\begin{array}{l}\text { Product } \\
\text { evaluation }\end{array}$ & Quality & Price & $\begin{array}{l}\text { Unique } \\
\text { ness }\end{array}$ & $\begin{array}{l}\text { Functio } \\
\text { nality }\end{array}$ & $\begin{array}{l}\text { Transp } \\
\text { ort }\end{array}$ & Colors & $\begin{array}{l}\text { Diversi } \\
\text { ty }\end{array}$ \\
\hline $\begin{array}{l}\text { Not at all } \\
(\mathbf{1})\end{array}$ & 5 & 9 & 8 & 10 & 10 & 9 & 7 \\
\hline Little (2) & 4 & 6 & 3 & 14 & 3 & 4 & 8 \\
\hline $\begin{array}{l}\text { Average } \\
(3)\end{array}$ & 20 & 12 & 20 & 23 & 18 & 14 & 19 \\
\hline Good (4) & 20 & 17 & 19 & 11 & 19 & 23 & 16 \\
\hline $\begin{array}{l}\text { Excellent } \\
(5)\end{array}$ & 15 & 22 & 13 & 5 & 13 & 16 & 12 \\
\hline $\begin{array}{l}\text { Do not } \\
\text { know }\end{array}$ & 37 & 35 & 38 & 38 & 38 & 35 & 39 \\
\hline Total & 101 & 101 & 101 & 101 & 101 & 101 & 101 \\
\hline
\end{tabular}

Table 2: Evaluation of artisanal products by tourists (Authors) 


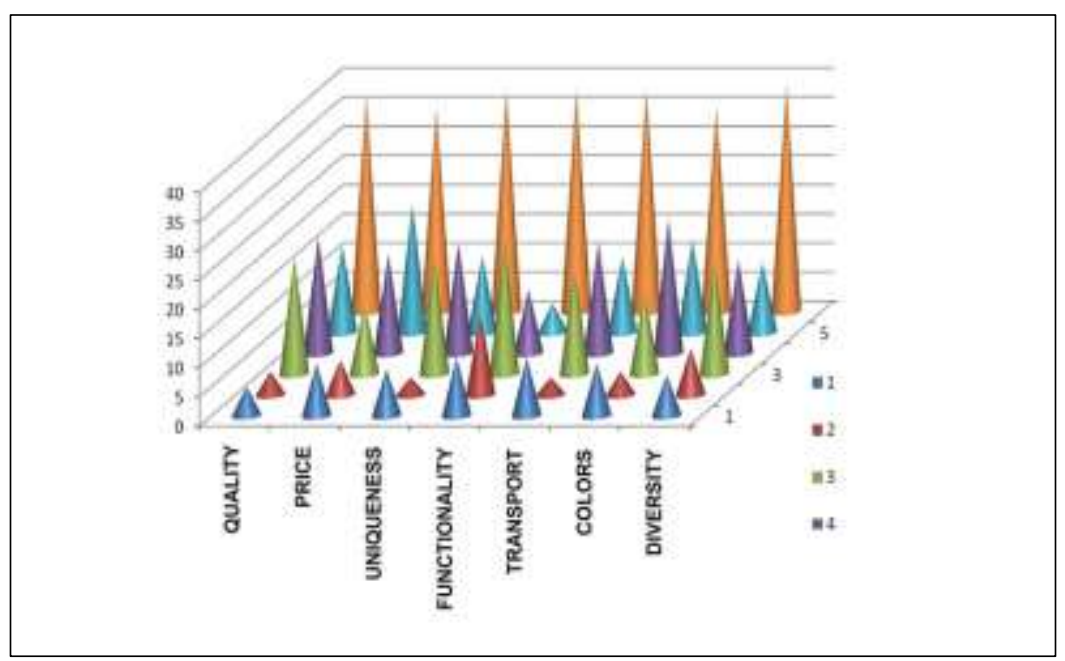

Figure 2: Graphic presentation of the evaluation of artisanal products by tourists (Authors)

It is easily noted, from Table 2 and Figure 2, that 35 to 39 percent of the tourists have no information on artisanal products. About 40 percent of the tourists surveyed evaluate quality as average and above average, meanwhile 15 percent of them think of it as excellent. Price is evaluated as not high by 22 percent of them, whereas 29 percent think of it as above average. Uniqueness is seen as average and above average by 39 percent of the tourists, but they are also keen to point out that some of the products are similar to those originating from Turkey or China. Functionality, which means that the product can be used for a special purpose apart from being a decoration object, is evaluated as average by 23 percent of the tourists surveyed, whereas 24 percent of them think they are of little functionality. Ease of transport is an important factor for the tourists when deciding to buy a product, and 50 percent of them think that the artisanal products are easy to transport (options 3 to 5). Colors are viewed as above average by 43 percent of them, even though some of the textile colors are out-of-date and the other part of tourists do not like so much the wide array of colors used. Diversity is well received and 47 percent of the tourists surveyed think of it as above average.

Tourists were also asked "How many artisanal products they bought during their stay in Shkodra?" and 70 percent of them had not bought anything at all. Meanwhile, 14 percent of those tourists had bought one or two products and 16 percent of them had bought more than three. When asked about the price of the products they bought, 30 percent of them had spent 1000 Lek, 23 percent of them from 1000 to 25000 Lek, 33 percent of them had spent from 26000 to 50000 Lek, and 13 percent of them over 50000 Lek.

The question "What would you wish to be different in the artisanal products?" was raised only to those tourists who had bought such products, and 23 percent of them stated that they would have liked a lot more variety and for the products to be more functional. Easier transport was also stated by 9 percent of the tourists.

\section{Conclusions and recommendations}

The research shows that there exists a connection between tourism and artisanry, which is also a possibility to empower artisanry. However, realization of this association requires a structured and integrated approach in order for the local and central government institutions and other organizations to support the creative business.

Artisans suffer the lack of market and sales channels. They sell their products through the direct channel, in their shops and fairs. They tend to see other sales channels as an after result of their growing business, and not as the primary cause of such growing business.

Tourists are generally ready to become customers of the artisans, since those who have been able to see the artisanal products have also purchased them. This association of tourists with artisanal 
products could be improved if some interventions were to be undertaken: better presentation of artisanal products to the tourists; adaptation of some of the products for their easier transportation (such as, improving wrapping service for paintings); improving the sales service (such as, learning English language); using internet for better promotion and distribution of information about artisanal products; cooperating with the tourist agencies in order to make their workshops and products part of the tours and fairs they organize; cooperating with hotels and restaurants.

The cultural system of a country holds up because of some actors, which make possible the protection and revitalization of its cultural and historic heritage. Artisans are usually found deep in rural areas and they are the only ones who have the knowledge about their crafts, which is thus at risk of going out without being inherited to the next generations. For many different reasons, creating a database on artisans and their crafts is of utmost importance, and this should be part of a government initiative. There were various initiatives to support artisanry, however drafting and approving a law on artisanry is now an urgent need, as well as establishing chambers of artisanry on various cities of Albania, registering all artisans as per their craftsmanship, looking for markets to sell artisanal products in Albania and abroad, and training and developing their skill in accordance to challenges of time.

Lack of access on information about government and non-government organizations grants for artisans makes it an imperative for public institutions to take on themselves the responsibility for more coordination, inclusion, marketing and patenting of artisanal products.

It is also an imperative to mediate and set up cooperation arrangements between artisans and tourist operators, as well as to establish the Academy of Artisanry, which would be a vocational school to revitalize this priceless heritage of our culture, and search for public-private partnership schemes, starting with fiscal incentives (such as, a tax free period of 5 years for newly set-up artisans, a relief period of 3 years from payment of social security for newly set-up businesses) and offering soft loans to artisanal businesses.

This research, of associating artisanry with tourism, could be extended to other regions of the country, and its data and findings can be generalized in order to create a database of indicators to show the connection there is between tourism and the development of artisanry (which is also one of the objectives singled out in the International Symposium on "Crafts and the International Market: Trade and Customs Codification”, Manila, The Philippines, 6 - 8 October 1997) (UNESCO, 1997).

\section{Bibliography}

1. intracen.org. (2015, June). International Trade Center. Retrieved June 22, 2015, from intracen.org: http://www.intracen.org/itc/sectors/creative-industries/

2. ITC, W. (2003). Marketing Craft and Visual Arts: The Role of Intellectual Property. Geneva: ITC, WIPO.

3. Kola, B. (2013). Marketingu i Produkteve Artizananle. (pp. 29 - 31). Durres, http://www.uamd.edu.al/

4. Nugue, J. E. (1990). Crafts: Methodological Guide to the Collection of Data on Crafts. UNESCO.

5. Nxitja e Punësimit të të Rinjve. (2014, October 1). Retrieved June 4, 2015, from artizanat.nbs.org.al, http://artizanat.nbs.org.al/2014/10/nbs-agjencia-nxitja-ebiznesit-social/

6. Plus, S. (2015, June 10). Star Plus "10 Qershor - Dita e Artizanatit". Retrieved June 15, 2015, from Star Plus TV, http://www.starplus-tv.com/sociale/item/607310-qershori-dita-e-artizanatit/

7. Report on Sustainable Tourism in the Mediterranean (2013). Brussels, Belgium: ARLEM.

8. SHGPAZ. (n. d.). Albania Network of Women Entrepreneurs. Catalogue, p. 15.

9. SHGPAZ. (2013). Vlerësimi i Mjedisit për Sipërmarrjen Femërore në Shqipëri. Tirane: ILO.

10. Shkoder, D. E. (2007). Artizanati. Shkoder: Ilar. 
11. Shoqata e Artizaneve (Artisans Association). (2015). Retrieved June 1, 2015, from artizanati.com, http://artizanati.com/

12. Tourism, Ministry of. (2014). Draft - National Tourism Strategy 2014 - 2020. Tirane: MZHUT.

13. UNDP, CIS, UNOPS. (2011, June). Strategic Plan for Sustainable Tourism in Shkodra Region. Retrieved June 23, 2015, from Slideshare, http://www.slideshare.net

14. UNESCO, I. (1997). International Symposium "Crafts and the International market: Trade and Custom Codification". Manila, The Philippines, unesdoc.unesco.org

\title{
Gaining Competitive Advantage in Tourism Marketing: A Text Mining Approach to Hotel Visitors' Comments in Durrës
}

\author{
Taşkın Dirsehan \\ Marmara University, Department of Business Administration (Lectured in English), \\ Istanbul, Turkey \\ taskin.dirsehan@marmara.edu.tr
}

\begin{abstract}
In recent years, data are exploded and they become more unstructured as a result of increasing web pages, e-mails, social media, photos and video contents. Traditional databases are not enough now to manage such data. However, organizations should manage them to gain competitive advantages; otherwise they will go out of play. As unstructured data are increased now, companies face with 'big data' and data mining tools should be applied to transform mass data into information and even into knowledge. There are different data mining techniques providing 'business intelligence'. One of them is text mining, a powerful tool to analyze texts as main unstructured data. They are mostly available in the tourism sector in the form of tourists' satisfaction and dissatisfaction stories. In this study, text mining technique will be applied to travelers' comments about hotels located in Durrës on booking.com. This web site collects travelers' positive and negative comments separately, so it enables to analyze comments in a bipolar way. In this case, the comments represent unstructured mass data and the competitive advantage will be the knowledge of attributes of satisfaction and those of dissatisfaction. Based on the research findings, these attributes will be discussed in details. Some of them are considered as 'standards', where their existence does not create satisfaction but their lack causes dissatisfaction. On the other hand, some of them are considered as 'providing competitive advantage', where their existence creates satisfaction.

Based on Herzberg's motivational theory, it's possible to state that hotel managers should eliminate dissatisfies to achieve a standard level. In addition they have to identify and then provide satisfiers to create competitive advantage which will result in travelers' satisfaction.
\end{abstract}

Keywords: Text Mining, Data Mining, Tourism Marketing, booking.com

\section{Introduction}

The last decade has provided more data than ever before. With the introduction of social media into daily lives, increasing amounts of technology enabling the monitoring of customers' and products' movements and electronic trade systems have provided unstructured and semi-structured data. These data are not suitable for traditional relational databases, which represent data in the form of columns and rows. These datasets are called "big data" (Laudon and Laudon, 2014). The big-data movement seeks to reveal intelligence from data and transform it into a business advantage (McAfee and 